\title{
ENHANCEMENT RESISTANCE OF TOMATO PLANTS INFECED WITH CUCUMBER MOSAIC VIRUS (CMV) THROUGH APPLICATION OF INTEGRATED SYSTEM OF MINERAL AND BIO-ORGANIC FERTILIZATION \\ Abass, Jehan M.* ; Manal A. Aziz ${ }^{\star \star}$; Ahlam A. Mehesen ${ }^{\star \star}$ and M. H. Elbagory** \\ Virus \& Phtoplasma Res.Dept., Plant Pathology Res. Inst.* ,Soil, Water and Environ.Res. Inst. ${ }^{\star \star}, A$. R. C., EGYPT
}

\begin{abstract}
A field experiments was conducted at sakha Agriculture Res. station to study the role of integrated system management of bio-organic fertilizers ( compost and compost tea) supplemented with selective strains of plant growth promoting rhizobacteria (PGPR) in combination with different levels of mineral fertilization, for enhancing protection of tomato plants against cucumber mosaic virus (CMV). In this study split plot design was applied where the main plots were randomly infected with or without viral infection, while the sub main plots were assigned by treated with bioorganic fertilizers and different levels of mineral fertilizers. Measurements of plant growth parameters including plants morphology (length and diameter of Fruits) , of tomato yield and its chemical components (T.S.S, acidity, $\mathrm{N}_{2}, \mathrm{P}_{2} \mathrm{O}_{5}$ and osmotic pressure ) were examined, as well as the activities of Peroxidase and polypheyloxidase enzymes were reported. Cucumber Mosaic Virus ( CMV) was isolated From naturally infected tomato plants and identified according the recommended methods.

Optained the results could be summarized in the following points:

1- Plants without viral infection showed significant improvements of all the tested parameters due application of enriched bio-fertilizers individually or in combination with mineral fertilizers. Plots that received $6.7 \mathrm{~kg}$ compost $+60 \% \mathrm{~N}_{2}+$ Compost tea was the best and showed superiority as compared with other treatments.

2- Plant infected with virus, showed considerable reduction loss in all the tested parameters as result of the viral disease as compared with healthy plants that not infected with (CMV). Although diseased plant showed less values but it was higher than the unfertilized

3- Plants infected with CMV and fertilized with bio.organic fertilizers (compost and compost tea ) and mineral fertilizers showed a clear recovery in all the tested growth parameters and disease severity was reduced as compared with infertilized ones.

4- As for example, the calculated data of the percentage changes of tomato yield (treatment received $6.7 \mathrm{~kg}$ compost and $60 \% \mathrm{~N}$ and with compost tea sprayed)showed an increase of $19 \%$ of healthy plants as compared with respective control (2539.5and $2129.5 \mathrm{~kg} / \mathrm{fed}$.), loss of $48.7 \%$ due to viral infection (2129.5 and $1123 \mathrm{~kg} / \mathrm{fed}$ ) and clear recovery of about $25.8 \%$ in diseased plants due to fertilization treatments (1123.25 and $1413.6 \mathrm{~kg} / \mathrm{fed})$.

5- The beneficial effects of the used treatment were extended to increase the activity of peroxidase and polyphenoloxidase enzymes in comparison with control plants. Data obtained clearly showed that application of suggested biofeitilizers increased the defensive capacity of tomato plants against the harmful effect of CMV.
\end{abstract}




\section{INTRODUCTION}

Tomato (lycopersicun escupentum Mill) is one of the most vegetable crop cultivated in different localities in Egypt as well as in different parts of the world. If is considered one of the most solansaceous crop that can be grown at all times of the year in Egypt.

Unfortunately, tomato crop are subjected to several pathogen ( fungi, bacteria and virus) One of the most important disease that causes severe damage is cucumber mosaic virus ( CMV) as the loss of tomato yield due to this disease is about $10-20 \%$ (Thomas, and John, 2009).As, a general plant disease control can be achieved by a range of synthetic chemicals, but their use is becoming more and more controversial . Many investigations have indicated potentially undesirable effects on humans, Plants and other beneficial organisms. In addition upsetting the biological balance by toxic chemicals and can lead to severe outbreak of diseases. Consequently the need for more research into nonchemical methods seems to be justified than ever.

It is well recognized world-wide that application of integrated system of mineral and bio - fertilizers (compost, compost tea supplemented with selected strains of plant growth promoting rhizobacteria PGPR ) is continuously gaining a ground as this system can achieve the following purposes.

1- Conductive boosting for soil fertility and increasing crop production without causing environmental hazards.

2- Such system is often associated with increased rates of plant development and resistance against plant pests e.g. biocontrol agents ( Kloepper, 1993).and resistance against Cucumber mosais virus (Ali,et.al.,2012 and Naries, et.al.,2012).

There has been considerable interest in using compost. Compost tea is one promise bio fertilizer recently responsible for developing different management controlling program (Sheuerell and Mahaffee , 2002) . foliar spraying of compost tea has shown some potential for controlling a number of diseases, due to the presence of some microorganisms or there metabolites acted as PGPR and / or as biocontrol agents (Brinton,1995). Another postulated mechanism of compost tea as in , comparison with systemic acquire resistance (SAR), the term " induced systemic resistance" (ISR) is an alternative term sometimes used to denote induced resistance by nonpathogenic biotic agents e.g. PGPR (Van loon et.al.,1998). In addition the use of mineral fertilizer in this system has a special concern on the development of growth of tomato plants.

In the light of the presumptive evidence, the present study was carried out to evaluate the potential use of compost, compost tea and PGPR in combination with different levels of mineral fertilizer aiming to enhance protection of tomato plants against infection with cucumber mosaic virus (CMV). 


\section{MATERIALS AND METHODS}

A filed trail carried out at sakha Agriculture research station during season 2011/2012 aiming to study the role of integrated system management of mineral and organic fertilizers in protection tomato plants against viral diseases (CMV).The experimental design was spilt plot design with four replicates. The chemical analysis of the experimental soils are shown in table (1) .

Table (1):Some chemical and physical characteristics for the experimental soil

\begin{tabular}{|c|c|c|}
\hline Soil variable & \multicolumn{2}{|c|}{ Soil depth } \\
\hline & $0-30$ & $30-60$ \\
\hline $\mathrm{P}^{\mathrm{H}}$ & 8.20 & 8.10 \\
\hline $\mathrm{Ec}(\mathrm{ds} / \mathrm{m})$ & 3.26 & 2.82 \\
\hline SAR & 9.50 & 9.22 \\
\hline OM\% & 1.96 & 1.53 \\
\hline $\mathrm{CaCO}_{3} \%$ & 3.55 & 3.71 \\
\hline Porosity \% & 53.86 & 49.50 \\
\hline \multicolumn{3}{|c|}{ Soluble cations } \\
\hline $\mathrm{Na}^{+}$ & 22.15 & 19.17 \\
\hline $\mathrm{K}^{+}$ & 0.36 & 0.29 \\
\hline $\mathrm{Ca}^{++}$ & 6.85 & 5.93 \\
\hline $\mathrm{Mg}^{++}$ & 3.92 & 3.40 \\
\hline \multicolumn{3}{|c|}{ Soluble anion $\mathrm{meg} / \mathrm{L}$} \\
\hline $\mathrm{Cl}^{-}$ & 15.52 & 13.72 \\
\hline $\mathrm{HCO}_{3}$ & 5.67 & 5.18 \\
\hline $\mathrm{CO}_{3}^{--}$ & 6.00 & 0.00 \\
\hline $\mathrm{SO}_{4}^{-}$ & 12.09 & \\
\hline \multicolumn{3}{|c|}{ Partical sized distribution } \\
\hline Sand & 19.40 & 21.7 \\
\hline Silt & 24.30 & 20.10 \\
\hline Clay & 56.30 & 58.20 \\
\hline Textural & Caly & Clay \\
\hline
\end{tabular}

Where the main plot were randomly infected with or without (CMV) while the sub main plots were assigned by treated with bio-organic or mineral fertilizers in different proportions as follow:

1- Control (The recommended dose of mineral fertilizer )

2- Application of $6.7 \mathrm{~kg}$ compost / plot $+60 \% \mathrm{~N}$

3- Application of $20.5 \mathrm{~kg}$ compost $/ \mathrm{plot}+40 \% \mathrm{~N}$

4- Application of $28.2 \mathrm{~kg}$ compost $/$ plot

5- Application of $6.7 \mathrm{~kg}$ compost $/ \mathrm{plot}+60 \% \mathrm{~N}+$ Compost tea spray

6- Application of $20.5 \mathrm{~kg}$ compost $/ \mathrm{plot}+40 \% \mathrm{~N}+$ Compost tea spray

7- Application of $28.2 \mathrm{~kg}$ compost $/$ plot + Compost tea spray

All of the above mentioned treatments were carried out but for plants infected with (CMV).

Isolation and identification of CMV:

1- Virus isolation: samples of naturally infected tomato plants showing symptoms of disorders (mosaic, malformation and stunting) were collected from Kafr El -Sheikh governorate, Egypt. The virus was mechanically 
Abass, Jehan M. et al.

transmitted from infected tomato .Leaves to the tested plants. Inoculated plants were kept under greenhouse conditions and the symptoms were recorded after wards as follows:-

1. A. Symptomatology and host range:

Twenty four plant species belonging to seven plant families i.e Solanaceae, Cucurbetaceae, Chenopodiaceae, Leguminosae, Compositae, Cruciferae and Malvaceae were inoculated with extracted sap infected CMV virus under greenhouse conditions. Back inoculations were made on ch. amaranticolor in order to check the obscene of virus in symptomless plants.

1.B. Virus stability:

Dilution end point, thermal inactivation point and longevity in vitro were studied. Crude sap from infected tomato plants was used.

1.c. Indirect enzyme linked immuno sorbent assay (ELISA) method :

The indirect ELISA method was Carried as described by Converse and Martin (1990).

Determination of peroxidase (Po) and polyphenoloxidase (PPo) activity:

The main objective of determination these antioxidants enzymes to know its role in controlling Cucumber Mosaic Virus (CMV) on Tomato plants.

a. Crude enzyme preparation:

The activities of antioxidants enzymes were determined according to Maxwell and Bateman, (1967).

b. peroxidase assay:

The enzyme was determined according to the method described by and Srivastava (1987).

c. Polyphenoloxidase assay:

The enzyme activity was determined according to the method adopted by Matta and Dimond (1963).

* Total nitrogen was determined by microkjeldahl Method according to Jackson(1967) .

* Total phosphorus was measured colourimetrically using hydroquinone method as described by snell and snell(1967).

*Osmotic pressure values were calculated according to Gusava(1967).

*Juice sample were prepared for determining total soluble solids ( T.S.S) by using Gallilishand refractometer, total acidity \% was calculated as citric acid and total tannin according to A.O.A.C ( 1990) .

d. Compost tea Preparation and treatment:

Compost tea treatment. Aerated compost tea was prepared weekly in a $10 \mathrm{~L}$ bucket, with $0.4 \mathrm{~L}$ of compost and $2 \mathrm{~L}$ of tap water $(1: 5, \mathrm{v}: \mathrm{v})$, adapted from Weltzien (1991). Initially the mix was manually agitated and then aerated with a small air compressor (Rena Air 200, France) for 7 days. Before application, the compost tea was filtered through filter paper to remove large solid particles. The compost was obtained from market, urban and garden wastes composted in a tunnel system (Metrocompost S.A., Barcelona, Spain). This compost has been reported to be suppressive against Fusarium oxysporum f. sp. lycopersici, in tomato plants (Cotxarrera et al., 2002). 
Compost tea was sprayed five times (once per week), until the end of the experiment. No other materials were applied during the experiment. Chemical and properties of the compost tea are presented in Table (2)

Table 2. Chemical and characters of the compost tea.

\begin{tabular}{|l|c|}
\hline \multicolumn{1}{|c|}{ Property } & Compost \\
\hline Moisture & 36.2 \\
\hline Ph & 6.15 \\
\hline Ec (dsm ${ }^{-1}$ at $\left.25^{\circ} \mathrm{c}\right)$ & 10.62 \\
\hline O.M\% & 32.57 \\
\hline Total $\%$ & 1.21 \\
\hline Total $\% \%$ & 0.47 \\
\hline Total K\% & 0.80 \\
\hline $\mathrm{ca}++\%$ & 1.50 \\
\hline $\mathrm{Mg} \%++\%$ & 0.14 \\
\hline $\mathrm{Fe}(\mathrm{ppm})$ & 15068 \\
\hline $\mathrm{Mn}(\mathrm{ppm})$. & 598 \\
\hline $\mathrm{Zn}(\mathrm{ppm})$ & 65 \\
\hline $\mathrm{Cu}(\mathrm{ppm})$ & 57 \\
\hline
\end{tabular}

\section{Biochemical analysis:}

- Rhizobial Leguminosarum biofar vitiae strain No. 312317 was isolated from nodules of faba bean plants collected from kafr El-sheikh.governorate according to the procedure conducted by Vincent (1970) .

\section{Total Chlorophyll :}

Leaf total Chlorophy 11 content(SPAD unit) values was determined by using protable minolta Chlorophyll Meter ( Model SPAD-501). Leaf sample collected in mid-Gune and the reading was taken at the middle of leaf Blade according to Murquard and Timpton(1987)

\section{Statistical analyses:}

Randomized complete block design with three replications was used. Data collected were subjected to the statistical analyses according to the standard methods recommended by Gomez and Gomez (1984) using the computer program (IRRISTAT).

\section{RESULTS AND DISCUSSION}

Identification of CMV were based on four main characters including: Symptomatology, Hostrange ,Physical properties, ELISA. Symptomatology and host range : Results should that from 24 plant species belonging to 7 families mechanically inoculated with CMV, The host range and reaction of different plants are recorded in Table (3) and fig (1) . the tested plant species reacted with different responses . 10 plant species reacted systemically, two plant species react locally, two plant species react symptomlessly and ten plant species did not react any symptoms these results are in line with those obtained by (Andrew et al.,2007 and Dheepa and paranjo the, 2010). 
Abass, Jehan M. et al.

Table (3): symptoms and host range of cucumber mosaic virus (CMV)

\begin{tabular}{|c|c|c|c|}
\hline \multirow{2}{*}{ Host plants } & \multirow{2}{*}{ Symptoms } & \multicolumn{2}{|c|}{$\begin{array}{l}\text { Back inoculations } \\
\text { ch.amaranticolor }\end{array}$} \\
\hline & & $\begin{array}{c}\text { Inoculated } \\
\text { leaves }\end{array}$ & $\begin{array}{c}\text { Non-inoculated } \\
\text { leaves }\end{array}$ \\
\hline Fami. : Solanaceae & & & \\
\hline Lycopersicum esculentum mill. & M-Stu-Mal & + & + \\
\hline Capsicum annum L. & Sm-vc & + & + \\
\hline Datura stramonium $L$. & Samp & - & - \\
\hline Nicotiana glutinosa & Samp & - & - \\
\hline N.tabacum cv.samsun & M & + & + \\
\hline Fam : Cucurbitaceae & & & \\
\hline Cucumis sativus $L$. & $\mathrm{mM}$ & + & + \\
\hline Cucurbita pepo L. & M & + & + \\
\hline Fam: chenopodiaceae & & & \\
\hline Beta vulgaris $L$. & $M-V B$ & + & + \\
\hline Spinacea oleracea $L$. & M-Stu -VB & + & + \\
\hline Chenopoduim ameranticolor & NLL & + & - \\
\hline C.quinoa wild & CLL & + & - \\
\hline Fam : Legumimosae & M & & \\
\hline Phasolus vulgaris $L$. & - & + & + \\
\hline Pisum sativum $L$. & M & - & - \\
\hline Glycin max & - & + & + \\
\hline Vicia fabae $L$. & & - & - \\
\hline Fam: Compositae & M-stu & & \\
\hline Lactuca sativa $L$. & - & + & + \\
\hline Zinnia elagans Jacq. & & - & - \\
\hline Fam : Cruciferae & - & & \\
\hline Brassica rapa $L$. & - & - & - \\
\hline B.oleraceal L.var capitata & - & - & - \\
\hline B.oleraceal L.var botrites & - & - & - \\
\hline Raphanus sativus $L$. & - & - & - \\
\hline Eruca sativa Mill & & - & - \\
\hline Fam : Malvaceae & & & \\
\hline Gossypium barbadence & - & - & - \\
\hline Abelmoschus esculentes & - & - & - \\
\hline
\end{tabular}

Stu $=$ stunting $\cdot$ Mal $=$ Malformation. Sm $=$ servere mosaic $\cdot \mathbf{M}=$ Mosaic.

$\mathrm{mM}=$ Milfmosaic. $\mathrm{NII}=$ Necrotic local lesion. $\mathrm{Cll}=$ chlorotic local lesion samp= symptomless

$\mathrm{VC}=$ vein clearing. $\mathrm{VB}=$ Vien banding .

2- Virus stability : Results indicated that dilution end point $10^{-3}-10^{-4}$ ,thermal inactivation point was $55-60 \circ \mathrm{C}$ and infectivity is retained at room temperature for 2-3 days. These results agreed with those of ( Magdy et al, 2006).

3- ELISA: The studied virus was identified as cucumber mosaic virus (CMV) according to ELISA test in the Dept. of virus and phytoplasma Res., ARC, Egypt. 


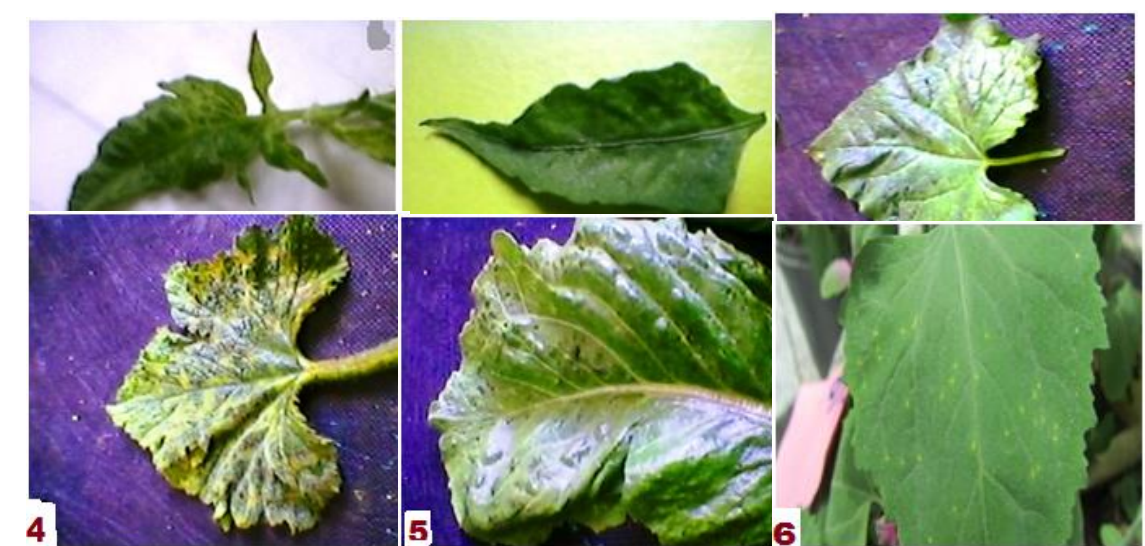

Fig(1) : Symptoms induced in some test plant following inoculation with Cucumber mosaic virus( CMV).(1) mosaic,stunting and malformation on Lycopersicum esculentum Mill.(2) severe mosaic and Vein clearing on Capsicum annum L.(3) mild mosaic symptoms on CuCucumis sativus L.(4)mosaic symptoms on Cucurbita pepo L.(5)mosaic and stunting on Lactuca sativa L.(6)Necrotic local lesion on Ch.amarnticolor.

\section{Effect of different treatments on some growth parameters of tomato} plants:

The effect of application of mineral fertilizers in combination with biofertilizeres (compost and compost tea) on the vegetative growth of tomato plants infected and non infected with CMV was evaluated, and the data are illustrated in Table (4)

In general all the tested showed a positive response in all tested parameters. The presumptine evidences obtained from viral identification tests highly recommended that the isolated virus is related to CMV. However tomato plants differed in their response according different treatments.

The highest value of the tested parameters was achieved in treatment that received $6.7 \mathrm{~kg}$ compost and $60 \%$ mineral nitrogen and compost tea spray as compared with other treatments. This was also, true for all tomato plants infected or non - infected with ( CMV) .

A similar positive effect due to application of different treatments but with less magnitude as compared with healthy plants. The above mentioned treatment still showed the superiority in achieving the highest values of all tested parameter even under the depressive effect the viral disease.

The beneficial effect of mineral and bio organic fertilizers are extended to tested to other tested parameters on both healthy and viral infected tomato plants including $\mathrm{N}_{2}$ and $\mathrm{P}_{2} \mathrm{O}_{5}$, osmotic pressure , total chlorophyll and acidity percentage contents of tomato plants as well as osmotic pressure and fruit yields (Table 5) .

It clearly obvious that application of compost and compost tea strengthened the positive effect of mineral nitrogen. The stimulation, varied however according to the level of mineral nitrogen. The highest average 
Abass, Jehan M. et al.

values still recorded to treatment received $6.7 \mathrm{~kg}$ compost , $60 \%$ mineral nitrogen and sprayed with compost tea .

Such increases in plant growth of tomato plants, the considerable reduction in diseases severity that account as a result of viral infection, and the clear recovery that obtained in all tested parameters could be attributed to the following point:

1- Application of mineral nitrogen fertilization led to much better use of phosphorus and other nutrient compounds required to tomato plants. It can help the plants to adjust the osmotic pressure inside plant cells as well as water balance between plant and soil. These results are in line with those obtained by El- Sanhoury (2003) and Soliman (2003).

2- Growth parameter is greatly affected as a result of bacterial activities present in compost and compost tea that led to increase the availability of water and mineral nutrients besides consists of essential components required to cell diseases. Cell elongation and photosynthetic pigments formation due its enriched in macro and micronutrients, phytohormones and vitamins (Ghobrial et.al 2009), (van loon et.al, 1998).

3- The presence of abundant microorganisms in compost and compost tea, besides their rule in nutrient and soil cycle and soil fertility, they provoke and increased the expression of natural defensive mechanisms of plants against various types of pathogen (Aglika Edceva,2004).

Table ( 4 ): Effect of different treatments on the tomato plant growth parameters

\begin{tabular}{|c|c|c|c|c|c|c|c|c|}
\hline & Treatments & $\begin{array}{c}\text { Total } \\
\text { chlorophyll } \\
\text { (SpAD } \\
\text { unit) } \\
\end{array}$ & $\begin{array}{l}\text { Length } \\
(\mathrm{cm}) \mathrm{f} .\end{array}$ & $\begin{array}{l}\text { Diameter } \\
(\mathbf{c m}) \mathrm{f} .\end{array}$ & $\begin{array}{l}\text { Fruit wt. } \\
\text { (g/plant) }\end{array}$ & $\begin{array}{l}\text { Volume } \\
\text { (ml) f. }\end{array}$ & & $A c$ \\
\hline \multirow{7}{*}{ 'E } & Control & $13.86 \mathrm{f}$ & $3.20 \mathrm{f}$ & $3.20 \mathrm{~g}$ & $84.10 \mathrm{~g}$ & $90.1 \mathrm{~g}$ & $3.60 \mathrm{~g}$ & $1.30 \mathrm{~g}$ \\
\hline & $6.7 \mathrm{~kg}$ compost $/$ plot $+60 \% \mathrm{~N}_{2}$ & $14.18 \mathrm{e}$ & $4.20 \mathrm{~d}$ & $5.40 \mathrm{e}$ & $88.6 \mathrm{e}$ & $91.1 \mathrm{e}$ & $4.8 \mathrm{e}$ & $1.60 \mathrm{e}$ \\
\hline & $20.5 \mathrm{k} \mathrm{g} \mathrm{compost} /$ plot $+40 \% \mathrm{~N}_{2}$ & $14.16 \mathrm{e}$ & $5.10 \mathrm{c}$ & $5.60 \mathrm{~d}$ & $90.30 \mathrm{~d}$ & $92.20 \mathrm{~d}$ & $5.00 \mathrm{~d}$ & $1.63 \mathrm{~d}$ \\
\hline & 28.2k g compost/plot & $15.02 \mathrm{~b}$ & $4.10 \mathrm{e}$ & $4.90 \mathrm{f}$ & $87.37 \mathrm{f}$ & $91.00 \mathrm{f}$ & $4.91 \mathrm{f}$ & $1.50 \mathrm{f}$ \\
\hline & $\begin{array}{l}6.7 \mathrm{~kg} \text { compost } / \text { plot }+60 \% \mathrm{~N}_{2}+ \\
\text { compost tea spray }\end{array}$ & $15.27 \mathrm{a}$ & $6.30 \mathrm{a}$ & $6.50 \mathrm{a}$ & $98.1 \mathrm{a}$ & $97.6 \mathrm{a}$ & $5.5 \mathrm{a}$ & $1.80 \mathrm{a}$ \\
\hline & $\begin{array}{l}20.5 \mathrm{k} \mathrm{g} \mathrm{compost} / \text { plot }+40 \% \mathrm{~N}_{2} \\
+ \text { compost tea spray }\end{array}$ & $14.57 c$ & $5.20 \mathrm{~b}$ & $5.90 \mathrm{~b}$ & $91.8 \mathrm{~b}$ & $94.6 \mathrm{~b}$ & $5.3 \mathrm{~b}$ & $1.78 \mathrm{~b}$ \\
\hline & $\begin{array}{l}28.2 \mathrm{k} \mathrm{g} \mathrm{compost} / \text { plot + compost } \\
\text { tea spray }\end{array}$ & $14.35 \mathrm{~d}$ & $5.20 \mathrm{~b}$ & $5.70 \mathrm{c}$ & $91.00 \mathrm{c}$ & $93.4 \mathrm{c}$ & $4.99 \mathrm{c}$ & $1.7 \mathrm{c}$ \\
\hline \multirow{9}{*}{ 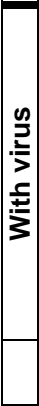 } & Control & $10.53 \mathrm{~g}$ & $3.00 \mathrm{~g}$ & $3.00 \mathrm{f}$ & $80.07 \mathrm{f}$ & $80.4 \mathrm{~g}$ & $3.20 \mathrm{~g}$ & $1.20 \mathrm{f}$ \\
\hline & $6.7 \mathrm{~kg}$ compost $/$ plot $+60 \% \mathrm{~N}_{2}$ & $11.00 \mathrm{e}$ & $4.80 \mathrm{e}$ & $5.00 \mathrm{~d}$ & $81.2 \mathrm{e}$ & $83.6 \mathrm{e}$ & $4.07 \mathrm{e}$ & $1.40 \mathrm{e}$ \\
\hline & $20.5 \mathrm{k}$ g compost/plot $+40 \% \mathrm{~N}_{2}$ & $11.07 \mathrm{~d}$ & $4.90 \mathrm{~d}$ & $5.10 \mathrm{c}$ & $88.8 \mathrm{~d}$ & $84.5 \mathrm{~d}$ & $4.35 \mathrm{~d}$ & $1.55 \mathrm{~d}$ \\
\hline & 28.2k g compost/plot & $10.87 \mathrm{f}$ & $4.20 \mathrm{f}$ & $4.30 \mathrm{e}$ & $83.10 \mathrm{f}$ & $81.2 \mathrm{f}$ & $4.6 \mathrm{f}$ & $1.40 \mathrm{e}$ \\
\hline & $\begin{array}{l}6.7 \mathrm{~kg} \text { compost/plot }+60 \% \mathrm{~N}_{2}+ \\
\text { compost tea spray }\end{array}$ & $12.57 \mathrm{a}$ & $5.80 \mathrm{a}$ & $5.60 \mathrm{a}$ & $93.60 \mathrm{a}$ & $96.00 \mathrm{a}$ & $5 \mathrm{a}$ & $1.75 \mathrm{a}$ \\
\hline & $\begin{array}{l}20.5 \mathrm{k} \mathrm{g} \mathrm{compost} / \text { plot }+40 \% \mathrm{~N}_{2} \\
+ \text { compost tea spray }\end{array}$ & $11.87 \mathrm{~b}$ & $5.1 \mathrm{~b}$ & $5.20 \mathrm{~b}$ & $91.40 \mathrm{~b}$ & $93.40 \mathrm{~b}$ & $4.9 \mathrm{~b}$ & $1.67 \mathrm{~b}$ \\
\hline & $\begin{array}{l}28.2 \mathrm{k} \mathrm{g} \mathrm{compost} / \mathrm{plot}+\text { compost } \\
\text { tea spray }\end{array}$ & $11.43 \mathrm{c}$ & $5.00 \mathrm{c}$ & $5.15 \mathrm{bc}$ & $90.00 \mathrm{c}$ & $92.00 \mathrm{c}$ & $4.7 \mathrm{c}$ & $1.60 \mathrm{c}$ \\
\hline & LSD. $5 \%$ & 0.065 & 0.065 & 0.065 & 0.065 & 0.079 & 0.017 & 0.017 \\
\hline & LSD 1\% & 0.088 & 0.088 & 0.088 & 0.088 & 0.106 & 0.023 & 0.023 \\
\hline
\end{tabular}


Effect of bio-organic and mineral fertilization on osmotic pressure.

Table (5) Regarding the Effect of bio-organic and mineral fertilization, the data exhibit gradual increase in osmotic pressure on tomatoes fruits as compared with control treatment. such results could be attributed to enhancement of metabolic activities devised by growth promoting substances secreted by beneficial microorganisms present in compost and compost tea .

Table (5): Effect of different treatments on tomato fruit yield (kg / Fadden), on $\mathrm{N}_{2}, \mathrm{P}_{2} \mathrm{O}_{5}$ fertilizers and on Osmotic pressure :

\begin{tabular}{|c|c|c|c|c|c|}
\hline & Treatments & $\mathbf{N}_{2}$ & $\mathrm{P}_{2} \mathrm{O}_{5}$ & $\begin{array}{c}\text { Osmotic } \\
\text { pressure (O.P) }\end{array}$ & $\begin{array}{l}\text { Yield } \\
\text { g/plant }\end{array}$ \\
\hline \multirow{7}{*}{ 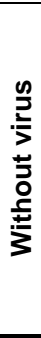 } & Control & $2.07 \mathrm{~g}$ & $0.43 \mathrm{e}$ & $9.18 \mathrm{~g}$ & $2129.50 \mathrm{~g}$ \\
\hline & $6.7 \mathrm{~kg}$ compost $/ \mathrm{plot}+60 \% \mathrm{~N}_{2}$ & $2.45 \mathrm{e}$ & $0.50 \mathrm{~d}$ & $10.88 \mathrm{e}$ & $2285.00 \mathrm{e}$ \\
\hline & $20.5 \mathrm{k}$ g compost $/$ plot $+40 \% \mathrm{~N}_{2}$ & $2.65 \mathrm{e}$ & $0.52 \mathrm{c}$ & $11.33 \mathrm{~d}$ & $2328.25 \mathrm{~d}$ \\
\hline & $28.2 \mathrm{k} \mathrm{g} \mathrm{compost} /$ plot & $2.35 \mathrm{f}$ & $0.48 \mathrm{e}$ & $10.68 \mathrm{f}$ & $2236.25 \mathrm{f}$ \\
\hline & $\begin{array}{l}6.7 \mathrm{~kg} \mathrm{compost} / \mathrm{plot}+60 \% \mathrm{~N}_{2}+\text { compost } \\
\text { tea spray }\end{array}$ & $2.61 \mathrm{a}$ & $0.53 \mathrm{a}$ & $12.18 \mathrm{a}$ & $2539.50 \mathrm{a}$ \\
\hline & $\begin{array}{l}20.5 \mathrm{k} \text { g compost/plot }+40 \% \mathrm{~N}_{2}+ \\
\text { compost tea spray }\end{array}$ & $2.59 \mathrm{~b}$ & $0.51 \mathrm{~b}$ & $12.10 \mathrm{~b}$ & $2523.14 \mathrm{~b}$ \\
\hline & $\begin{array}{l}28.2 \mathrm{k} \text { g compost/plot }+ \text { compost tea } \\
\text { spray }\end{array}$ & $2.52 \mathrm{c}$ & $0.49 \mathrm{c}$ & $12.09 \mathrm{c}$ & $2335.30 \mathrm{c}$ \\
\hline \multirow{9}{*}{ 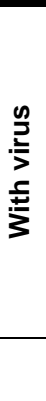 } & Control & $1.95 \mathrm{~g}$ & $0.28 \mathrm{e}$ & $8.58 \mathrm{~g}$ & $1123.25 \mathrm{~g}$ \\
\hline & $6.7 \mathrm{~kg}$ compost $/$ plot $+60 \% \mathrm{~N}_{2}$ & $2.28 \mathrm{e}$ & $0.36 \mathrm{c}$ & $10.78 \mathrm{e}$ & $1251.25 \mathrm{a}$ \\
\hline & $20.5 \mathrm{k}$ g compost $/$ plot $+40 \% \mathrm{~N}_{2}$ & $2.35 \mathrm{~d}$ & $0.40 \mathrm{~b}$ & $11.33 \mathrm{~d}$ & $1351.06 \mathrm{~d}$ \\
\hline & 28.2k g compost/plot & $2.05 \mathrm{f}$ & $0.38 \mathrm{~d}$ & $9.60 \mathrm{f}$ & $1212.50 \mathrm{f}$ \\
\hline & $\begin{array}{l}6.7 \mathrm{~kg} \text { compost } / \text { plot }+60 \% \mathrm{~N}_{2}+\text { compost } \\
\text { tea spray }\end{array}$ & $2.50 \mathrm{a}$ & $0.44 \mathrm{a}$ & $11.81 \mathrm{a}$ & $1413.60 \mathrm{a}$ \\
\hline & $\begin{array}{l}20.5 \mathrm{k} \text { g compost/plot }+40 \% \mathrm{~N}_{2}+ \\
\text { compost tea spray }\end{array}$ & $2.46 \mathrm{~b}$ & $0.42 \mathrm{~b}$ & $11.74 \mathrm{~b}$ & $1400.60 \mathrm{~b}$ \\
\hline & $\begin{array}{l}28.2 \mathrm{k} g \text { compost/plot }+ \text { compost tea } \\
\text { spray }\end{array}$ & $2.41 \mathrm{c}$ & $0.41 b$ & $11.70 \mathrm{c}$ & $1380.30 \mathrm{c}$ \\
\hline & LSD. 5\% & 0.017 & 0.017 & 0.017 & 0.017 \\
\hline & LSD 1\% & 0.023 & 0.023 & 0.023 & 0.023 \\
\hline
\end{tabular}

Anzyme activity :

As defensive indicators to the phytopathogens, enzyme activities of both Polyphenoloxidase (PPO) and Peroxidase (PO) of tomato plants were determined under natural infested field conditions. Both enzyme activities were assayed during five minutes (one for every one minute). For both enzymes, activities seem to be ascending increase during the measurement time course. Therefore, the last reading was considered and data were blotted in Fig. (2 and 3). Data illustrated that all treatments were pronounced in comparison with control of both enzymes. For peroxidase, Fig. 1 showed higher activity of the viral infected control plants in comparison with the non-infected ones. Due to treatments, activities of $\mathrm{PO}$ of the non-infected plants were clear increased compared with itself recorded in presence of the viral infection. It indicates induction of the systemic acquired resistance (SAR). PO of the plants inoculated with $40 \mathrm{~g}$ compost and $60 \% \mathrm{~N} 2$ as well as sprayed with compost tea reached to its higest activities of 5.00 and $4.00 \mathrm{OD} / \mathrm{min} / \mathrm{g}$ of both healthy and infected plants Respectively, superiority of the previous treatments was also obtained for PPO activities (Fig. 3), indicating accumulation of phenols in the plant tissues. 
Abass, Jehan M. et al.

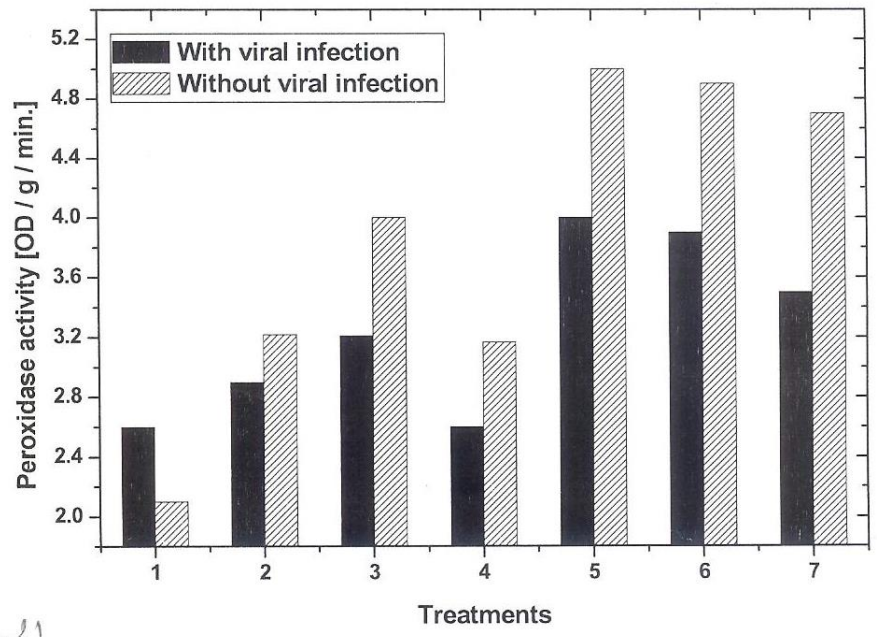

Fig2. Peroxidase activity in tomato plant:

1-Control. 2- $6.7 \mathrm{~kg}$ compost $/ \mathrm{plot}+60 \% \mathrm{~N}_{2} \quad 3-20.5 \mathrm{~kg} \mathrm{compost} / \mathrm{plot}+40 \% \mathrm{~N}_{2}$ 4-28.2kg compost/plot. $\quad 5-6.7 \mathrm{~kg}$ compost $/ \mathrm{plot}+60 \% \mathrm{~N}_{2}+$ compost tea spray 6-20.5kgCompost $/$ plot $+40 \% \mathrm{~N}_{2}+$ compost tea spray

7-28.2kg compost/plot + compost tea spray

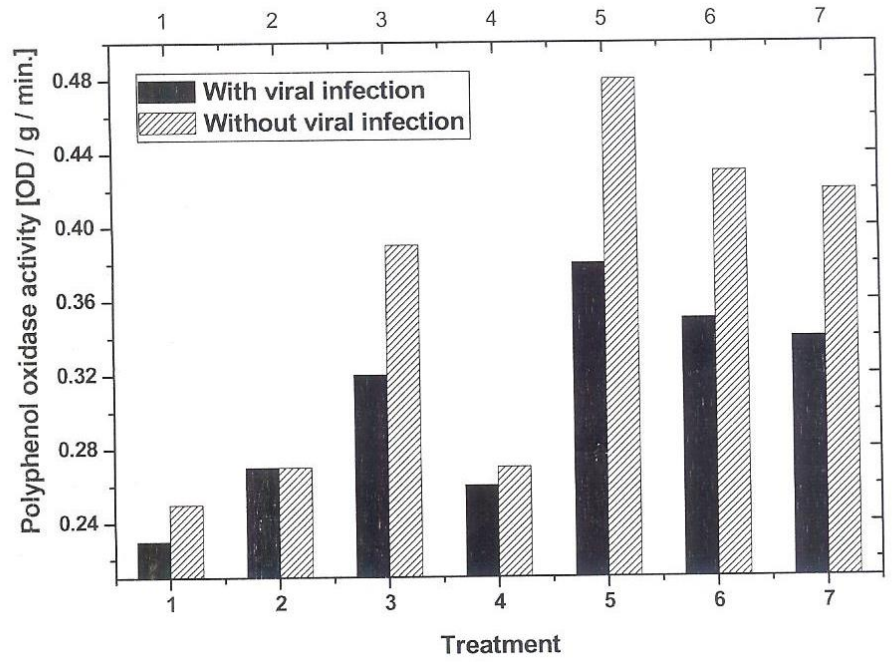

Fig.3.Polyphenoloxidase activity in tomato plant:

1-Control. $\quad 2-6.7 \mathrm{~kg}$ compost $/ \mathrm{plot}+60 \% \mathrm{~N}_{2} \quad 3-20.5 \mathrm{~kg}$ compost $/ \mathrm{plot}+40 \% \mathrm{~N}_{2}$ 4-28.2kg compost $/$ plot. $\quad 5-6.7 \mathrm{~kg}$ compost $/$ plot $+60 \% \mathrm{~N}_{2}+$ compost tea spray 6-20.5kgCompost $/$ plot $+40 \% \mathrm{~N}_{2}+$ compost tea spray

7-28.2kg compost/plot + compost tea spray 
Similarly, higher induction of PPO was observed in tea plants treated with Pseudomonas fluorescens lead to accumulation of higher phenolic compounds, which may play an important role in defense mechanism in plants against pathogen (Sivakumar and Sharma, 2003). It is worthy to mention also that the plants inoculated only with $120 \mathrm{~g}$ compost induced the lowest activities of both PO and PPO enzymes for the healthy and infected plants, indicating lower induction of SAR in the plant tissues. These consequences are in agreement also with the findings of Saravanakumar et al. (2007), who found remarkable increase in PPO and $\mathrm{PO}$ activities in tea plants treated with $P$. fluorescens in comparison with the untreated plants.

It could be concluded that the obtained result indicate the defensive capacity of tomato plants against CMV Could be enhanced through the synergistic effect of mineral nitrogen when combined with bio-organic fertilizer of compost and compost tea.

Foliar fertilization with compost tea with its remarkable nutritional values that are present in soluble chemical compounds into an a queans sphere play an important role in controlling several plant diseases and it contains beneficial biotic agents that can induce systemic resistance in plants . In addition such treatments . some at Least $40 \%$ of mineral nitrogen and minimized pollution of environment caused by excess of application mineral nitrogen.

\section{REFERENCES}

Ali M.El- Borollosy and Mona M.Oraby (2012). Induced Systemic resistance against Cucumber Mosaic Cucumovirus and promotion of Cucumber growth by some plant growth promoting rhizobacteria. Annals of Agricultural Sciences volume 57 , Number 2 : 91-97.

A.o.A.c (Association of official Agriculture chemists)(1990). Official methods of analysis, $15^{\text {th }}$ ed.,Washington D.C.,USA.

Andrew, J.M.Carole Arnata and Margaret , I.B. (2007) : sources of natural resistance to plant viruses : statues and prospects. Molecular plant pathiology. 8(2).223-231.

Bollen , G.J.(1993) factores involved in inactivation of plant pathogens durieng composting of crop residue . in science and Engineering of composting : Design. Enviromental microbiological and vtilization Aspects, eds Hoitimk HAJ\&keener HMPP: 301-318. Washingtom DC:Renaissance.

Brinton, W. (1995). The control of plant pathogenic fungi by use of compost tea. Biodynamics, 197: 1215.

Cotxarrera L. Trillas -Gay M.I., steinberg C., Alabouvette C., 2002 Use of sewage sludge compost and trichoderma asperellum isolates to suppress fusarium wilt of tomato. Soil Biology and Biochemistry 34 : 467-476 
Creacezi, A.,Barbarossa, L.,Cillo,F.,Franco , A.,valvas, N.and Gallitelli , D.(1993) Role of cucumber mosaic virus and its satellite RNA in the etiology of tomato fruit mecrosis in Italy.Arch. virol.131:321 -333.

Converse, R. and Martin, R.(1990). Enzyme-linked immune sorbent assay(ELISA).In: serological methods for detection and identification of viral and bacterial plant pathogens .(R Hampton, E Ball, Sde Boer, eds.),APS press, Saint paul, MN,USA, 179-196.

Edreva, A.(2004).Anovel strategy for plant protection : Induced resistance. Journal of cell and moleculer biology.3: $61-69$.

EL-Sanhoury, A. M. (2003). Studied on drought tolerance of three apricot varieties. M. Sc. Thesis,Fac. Agric., Kafr EL-Sheikh, Tanta Univ., Egypt.

Ghobrial, W.N., Ahlam A. Mehesen, Jehan M.Abass,M.E.Shalaby and A.F. Omar(2009). Potential impacts of rizobium and compost tea enriched with rhizobacteria for enhancing protection of faba bean against broad bean mottle virus(BBMV). J.Agric. Res. Kafr EL-Sheikh Univ.,35(1)

Gomez, K. A. and A.A.Gomez (1984). Statistical Procedures for Agricultural Research $2^{\text {nd }}$ Ed; John Weley and Sons, Inc. New York.

Gosava, N.A(1967). Some methods in studying plant water relation linngrad Acad. Of science. Ussr.

Jackson, M.L.(1967). Soil chemical analysis. Prentice - Hall of India Private, New Delhi.

Kloepper, J.w.(1993). Plant growth =promoting rhizobacteris as biological control agents .pages $255=274$ in FB metting , Jr editor. Soil microbial Ecology . Marcel Dekker, Newyork.

Magdy,S.M.,Nerjen,H.D.,Neda,Y.A.R.G.Bhard waj and B.Al-Hamar (2006) Occurrence of three strains of cucumber mosaic virus Affecting Tomato in Kuwait. Plant pathol.J.22(1):51-62

Matta,A. and A.E.Dimond(1963). Symptoms of Fusarium wilt in relation to quantity of fungus and enzyme activity in tomato stems. Phytopatho531:574 - 575.

Maxwell, D.P. and D.F. Bateman (1967). Changes in the activities of some oxidase in extracts of Rhizoctonia-infected have been hypocotyls in relation to lesion maturation. Phytopath.57:132-136.

Murquard,R.D. and J.L. Timpton (1987) .Relationahip between extrattable chlorophyll and an in situ method to estimate leaf grain.Hort.Sci.22(6):1327

Moran, R., 1982. Formulae for determination of chlorophyllous pigments extracted with N, N. Dimethyl formamide. Plant physiol.69: 1376-1381.

Naries H. Dashti, Nedaa Y. Ali, Vineetha M. Cherian, and Magdy S.Montasser(2012). Application of plant groeth - promoting Rhisobacteria (PGPR) in combination with mild strain of $\mathrm{Cu}$ Cumbermosaic virus ( $\mathrm{CMV}$ ) associated with viral satellite RVAS to enhance growth and protection against a virulent strain of CMV in tomato. Canadian Journal of plant pathology, volume 34, Number 2 : 177-186. 
R.Dheepa ands.Paranjthi (2010). Transmission of cucumber mosaic virus (CMV) infecting banana by a phiel and mechanical metholds. Emir.J.food Agric .22 (2): 117-129.

Saravanakumar, D.,C.Vijayakumar, N. Kumar and R. Samiyappan (2007).

PGPR-induced defense redponses in the tea plant against blister blight diseasa .Crop prot.,26:556-565.

Scheuerell, S. and W. Mahafee (2002). Compost tea principles and prospects for plant disease control. Compost Science and utilization 10 (4): 313 338.

Seo,y.S.Rojas,M.R.Lee, J . y. lee, S. W. Jean J.S., Ranald,P.,Luca, W.J.And Gilbertson, R.L.(2006).Aviral resitance gene from common been functions across plant families and is up -regulated in non-virusspeafic manner.Proc.Natl Acad.SciUSA,103,11856-11561

Snell, F.D.and C.TR. snell (1967). Clorimentric methods of Analysis. D.van Nostrand Company , Irc., $551-552$.

Soliman, M. A. (2003). Effect of foliar spray nutrients on water relationships of some young deciduous fruit trees. M. Sc. Thesis, Fac. Agric., Kafr Elsheikh, Tanta Univ., Egypt.

Srivastava, S.K. (1987). Peroxidase and Polyphenol oxidase in Brassica juncea plants infected with Macrophomina phaseolina (Tassi. Goid.) and their implication in disease resistance phytopathol., 120: 249-254.

Thomas, A. Zitter and John, F.Murphy (2009). Cucumber mosaic Virus. The plant Healthy I snstructer. Do 1:10 . 1094/PH 1.10.2009 - 0518-01.

Van Loon, L. C., P. A. Pakker and M. J. Pieterse (1998). Systemic resistance induced by rhizosphere bacteria.Ann. Rev. phytopathol., 36:453-483.

Vicent, G.M.(1970). Amanual for the practical study of root-nodule bacteria. I.B.P hand book, No 15, Black well Scientifc publication. OXFord and endinburgh,. PP:54-58.

Weltzien H.C.(1991).Biocontrol of foliar fungal diseases with compost extracts.In:Andrewsa j.H., Hirano S., (eds). Microbial Ecology of leaves, pp. 430 - 450. Springer - verlag, New York, NY, USA.

Zayan, M. N.; A. F. EL- Sammak; S. M. Zeerban and A. R. EL-Sherif (2002). Physiological responses of some grape vines varieties to drought condition $2^{\text {nd }}$ Inter. Conf. Hort. Sci., Kafr EL-Sheikh, Tanta Univ., Egypt, PP. $782-795$. 


\section{Abass, Jehan M. et al.}

تحسين مقاومـة نباتـات الطمساطم المصـابة بفيروس موزيك الخيـار باستخدام نظـام متكامل للاسمدة المعدنية و العضوية العنات الحيوية (CMV)

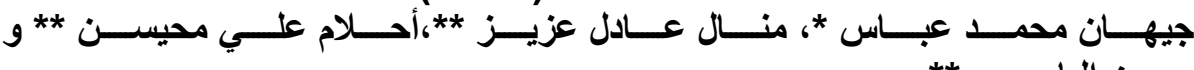
محسن الباجوري مجري

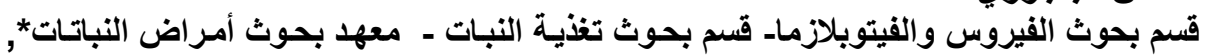

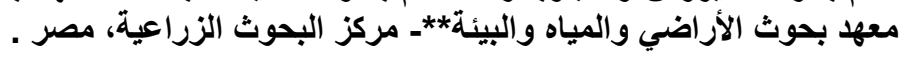

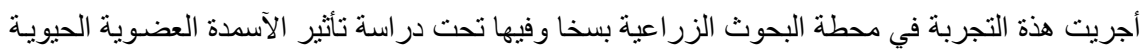

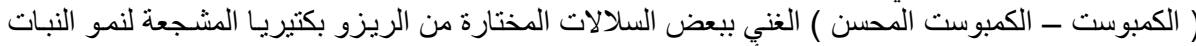

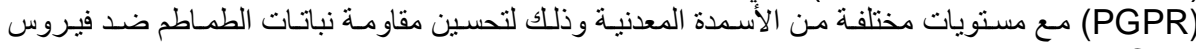

1- ظهر تحسين معنوي واضح في كل الصفات المختبرة للنباتات الغير ملقحة بالفيروس بسبب استخدام

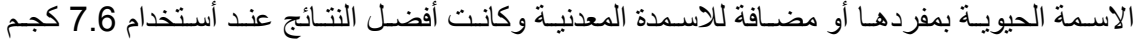
كمبوست + 60\% نيتروجين + كمبوست محسن ( المعاملة المثلي ) .

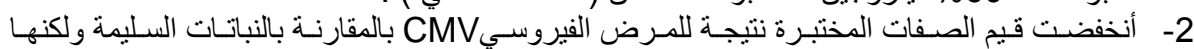
ماز الت أفضل من النباتات الغير مسمدة .

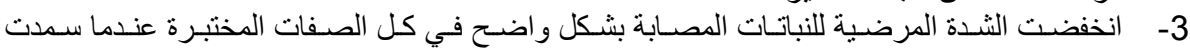

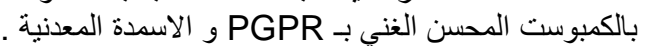

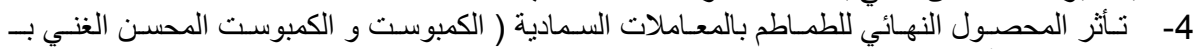

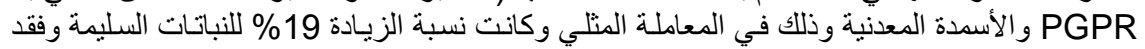

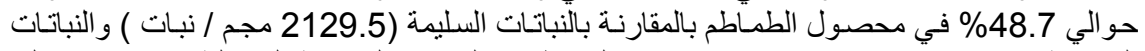

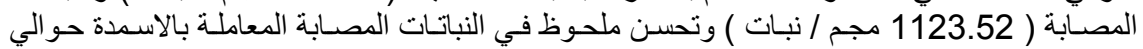
17.3 ( 1413.6 ( 14.6 مجم / نبات ).

5- كفاءة استخدام هذة الأسمدة قد أمتدت أيضا إلي زيادة النثاط الانزيمي لكل من البيروكسيديز و البولي

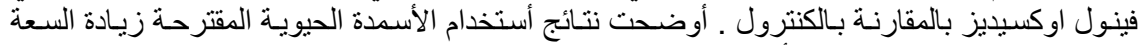

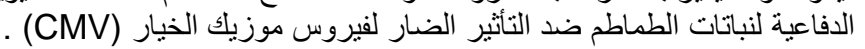

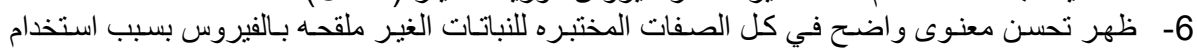

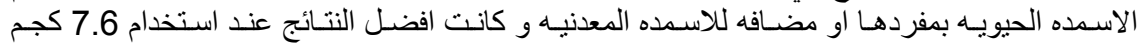
كمبوست + 60\% نيتروجين + شاى كمبوست المحسن (المعامله المثلى).

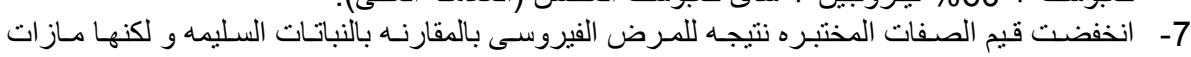
افضل من النباتات الغير المسده.

كلية الزراعة ـ جامعة المنصورة

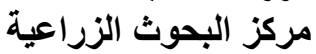

قام بتحكيم البحث أ.د / فتحى اسماعيل حوقه الته

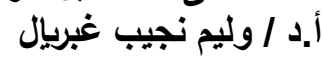

